\title{
LEGAL ENFORCEMENT OF INNOCENT PASSAGE IMPLEMENTATION IN INDONESIAN WATERS
}

\author{
Eka Widi Astuti \\ Master of Law at Airlangga University \\ email:widieka@hotmail.com \\ Oki Kustiwa \\ Master of Law at Airlangga University \\ email: o.kustiwa@gmail.com

\section{Arief Syahroni} \\ Master of Law at Airlangga University \\ email: ariefsyahroni90@gmail.com \\ Wahyu Subagyo \\ Master of Law at Airlangga University \\ email: wsubagyo80@gmail.com
}

\begin{abstract}
Indonesia is geographically located in a strategic position between two continents, Asia and Australia, and two oceans, the Pacific and Indian Ocean. This factor allows many foreign ships to pass or anchor within Indonesian waters for trade and military purposes. Right of innocent passage applies to foreign ships and aircraft within the territorial sea. Foreign ships and aircraft are not allowed to engage in activities or crimes endangering the sovereignty of a nation or perform any violations towards the right of innocent passage. The legal purpose of this research is to know whether innocent passage endangers national sovereignty and learn how the law enforcements protect Indonesian territorial sea from foreign ships. The use of normative legal research reveals that the right of innocent passage in Indonesian waters is regulated in Law No. 17 of 1985 made as a ratification for the 1982 UNCLOS and the Institutions authorized to perform law enforcement in the sea through the employment of patrol task forces, namely Indonesian Naval force, Directorate of Water Police, Ministry of Maritime Affairs and Fisheries and Indonesian Maritime Security Board.
\end{abstract}

Keywords: Indonesia, Innocent Passage, Legal Enforcement, Territorial Sea

\section{INTRODUCTION}

Indonesia is geographically located in a strategic position between two continents, Asia and Australia, and two oceans, namely the Pacific and Indian Ocean. It is deemed as strategic because it is blessed with the potential of biological and non-biological resources. Furthermore, Indonesia's strategic location makes Indonesian waters one of the most important international navigation lanes in the world. This factor allows many foreign ships that pass or anchor within the Indonesian sea area for trade and military purposes. The sea is a highway that connects all corners of the world, people from various nations have exchanged many things using, from commodities to knowledge, using this highway. ${ }^{1}$

\footnotetext{
${ }^{1}$ Youla Olva Aguw, Pengaturan Pemanfaatan Sumber Daya Alam Laut Dan Pesisir Berbasis Penegakan Hukum Dan Keadilan, Lex Et Societatis,Vol. I, No. 5, September 2013, P. 146.
} 
The marine security of waters within national jurisdictions and international waters used as navigation lanes has long been a serious global concern, especially for Coastal States and Archipelagic States directly having interests in them. One of the functions of the sea is as a transportation route that connects one country to another for the benefit of various types of activities. This function is of a high value for archipelagic States. However, marine crimes often occur in the sea and thus becoming a threat to voyages and shipping security. Such crimes often result in the loss of crew life, physical damages to ships, lost of goods transported and losses suffered by the ship owners.

Each State basically has the right to sail in its own territorial sea, Exclusive Economic Zone (EEZ), high seas and the territorial sea of other States. However, when it comes to the right to navigate the sea or territorial waters of other countries, a State is regulated by the Convention on the Law of the Sea I of 1958 and Article 17 of the Convention on the Law of the Sea (UNCLOS) II of 1982:

Innocent Passage: "Ships of all States, whether coastal or land-locked, enjoy the right of innocent passage through the territorial sea."

Article 19 paragraph 1 further formulates "innocent passage" as: "A passage is innocent so long as it is not prejudicial to the peace, good order or security of the coastal State. Such passage shall take place in conformity with this Convention and with other rules of international law." 3

Basically, any navigation by foreign ships are protected by the right of innocent passage. However, there are many who misuse these rights, and thus endangering Indonesia's territorial integrity.

Illegal fishing cases usually occur in the EEZ, Territorial Sea, Natuna Sea, North Sulawesi Sea and Arafura Sea. The waters of North Sulawesi are one of the red zones of illegal fishing. This area has become a fishing zone for fishing ships from several countries wanting to extract the nation's abundant fishery resources, especially commodities such as tuna and skip jack tuna. The perpetrators generally only want to earn quick money, stealing maritime wealth by resorting to robberies or piracies. ${ }^{4}$

Illegal fishing by foreign ships is carried out openly, using seines (large nets) to catch fish of different sizes, from small fish to large fish. There are many modi operandi adopted by the perpetrators. One of them is where they hire local fishermen and flagged foreign ships. These men and ships will then be ordered to sail under the Merah Putih (the flag of the Republic of Indonesia) even though they do not have the permit needed to fish in Indonesian waters. ${ }^{5}$ In addition to illegal fishing cases, there are also cases pertaining to right of innocent passage in Indonesian waters, namely the expulsion of the Lusitania Espresso by the Indonesian government on March 11, 1992. The Lusitania Expresso is a Portuguese-flagged ship carrying the Anti-Integrity Group from Portugal. This ship sailed from Lisbon, Portugal to Dili with the purpose of scattering flowers on the graves in the Santa Cruz cemetery, Dili. The Indonesian government, which previously had a conflict with the Pro-Independence East Timorese on 12 November 1991, deemed the Anti-Integrity Group's mission to be reeked of political provocations and allegedly supported by the government of Portugal. As a response to this provocative mission, the Indonesian government sought to suppress the group by forming Aru Jaya Task Force.

\footnotetext{
${ }^{2} 1982$ Sea Law Convention (1982 UNCLOS).

${ }^{3}$ Ibid.

${ }^{4}$ Cornelis Djelfie Massie, Law Enforcement Practice of Illegal Fishing in North Sulawesi Waters, Journal of Law, Policy and Globalizations, ISSN 2224-3240, Vol 40, 2015, P. 15.

${ }^{5}$ Ibid.
} 
Its main task was to expel the Lusitania Expresso and prevent them from going on a pilgrimage tothe Santa cemetery Cruzin East Timor.

The expulsion of Lusitania Expresso by the Indonesian government shows that an innocent passage can be limited if it is deemed to be violating or endangering the sovereignty of a country. However, on the other hand, the sovereignty rules of a country cannot limit or violate the innocent passage of other countries during their navigations.

The passage of ships sailing under the right of innocent passage as well as the rights and the obligations of coastal States in relation to their own regulations is regulated in 1982 UNCLOS articles 20 to 32.

Based on the description above, there are 2 (two) problems that will be examined, namely:

a. Does Innocent Passage Implementation Endanger the Sovereignty of a Country?

b. HowisInnocentPassageEnforcementagainstForeignShipsin theIndonesianTerritorial Sea performed?

This research employs a normative legal research. Normative legal research, which is also known as the library research, is a legal research conducted by examining library materials or secondary data only. The data used in this research are secondary data and primary data. The secondary data were obtained from relevant literature, articles and journals obtained during the library research. Meanwhile, the primary data is data directly obtained from the source or location of the research object. ${ }^{6}$

\section{DISCUSSION}

\section{Innocent Passage Implementation}

\section{Innocent Passage according to 1982 United Nation Convention on the Law of the Sea(UNCLOS)}

According to the provisions of International Law of the Sea, within their respective territorial sea, coastal States implement and Haven absolute territorial sovereignty over its waters, the land below it, all of the natural wealth within it and air above it, provided that foreign ships will still have their innocent passage guaranteed as long as they comply with and pay attention to the provisions of the international law on innocent passage. ${ }^{7}$

Thus, ships from all countries have the right of innocent passage to safely sail through a country's territorial sea during peace time. This globally recognized right of innocent passage can also be seen as a wise opportunity that can be utilized in the interest of both maritime transportation and the coastal States.

Article 52 on the right of innocent passage of the 1982 United Nation Convention on the Law of the Sea reads as follows:

a) Subject to article 53 and without prejudice to article 50, ships of all States enjoy the right of innocent passage through archipelagic waters, in accordance with Part II, section 3.

b) The archipelagic State may, without discrimination in form or in fact among foreign ships, suspend temporarily in specified areas of its archipelagic waters the innocent passage of foreign ships if such suspension is essential for the protection of its security. Such suspension shall take effect only after having been duly published. ${ }^{8}$

Article 52 paragraph 1 states that an archipelagic State must respect the right of innocent passage of any foreign ships passing through its archipelagic waters (the

\footnotetext{
${ }^{6}$ Sugiyono, Metode Penelitian Kuantitatif dan R\&D, Alfabeta, Bandung, Cet. Ke 8, 2008, P. 137.

${ }^{7}$ Swift, Richard. N., International Law, Current Clasic, 1969, P. 228.

${ }^{8}$ hukum.unsrat.ac.id/hi/unclos_terjemahan.doc
} 
provisions in chapter II, the third part of the convention) and that it may determine the boundary of their inland waters by establishing closing lines to clearly define the area where a passing ship is considered to be exercising the right of innocent passage.

Meanwhile, Article 53 paragraph (3):

"Archipelagic sea lanes passage means the exercise in accordance with this Convention of the rights of navigation and over flight in the normal mode solely for the purpose of continuous, expeditious and unobstructed transit between one part of the high seas or an exclusive economic zone and another part of the high seas or an exclusive economic zone."

Even when using archipelagic sea line passage, then any passing ships can use normal mode in the meaning of sailing normally, should not be restricted and unobstructed passage $^{9}$ for example submarine could cross an archipelagic sea line without being disturbed and with a fixed position dive in the water just as sailing on the high seas. This is certainly different from the right of innocent passage in the territorial sea, where at the time of sailing ships then the subs are required to navigate on the surface of the water and show the flag. ${ }^{10}$

Article 19 paragraph (1) of the UNCLOS defines the innocent passage as: "Passage is innocent so long as it is not prejudicial to the peace, good order or security of the coastal State. Such passage shall take place in conformity with this Convention and with other rules of international law." 11

This article affirms that the right of innocent passage applies to every coastal and land-locked States'ship sailing through the territorial sea of another country as long as it is not detrimental to the peace, order or security of the coastal State. From this article, it is apparent that, in certain circumstances where the right of innocent passage is implemented, the coastal State concerned may suffer from some losses.

Even though other states may have the right of innocent passage, a coastal State may still be able to suspend or even ban or restrict ships from passing through its territorial sea because the sea lies within the sovereignty zone of the said coastal State. A suspension can be performed provided that the coastal State is conducting a combat training or has clearly defined reasons, such as for the protection or safety of the State. ${ }^{12}$

For the safety of its sea traffic, a coastal State may require foreign ships to go through specific sea lanes in exercising their right of innocent passage in its territorial sea and comply with the rules regarding the separation of sea traffic. For this reason, an archipelagic State must also determine the sea lanes in accordance with the provisions of the convention and can also establish a traffic separation scheme to maintain the safety of ship traffic. If there is a change in the sea lanes, an archipelagic State shall announce such change accordingly.

Regarding a coastal State's laws and regulations governing the right of innocent passage, article 21 paragraph 1 of 1982 UNCLOS states that:

The coastal State may adopt laws and regulations, in conformity with the provisions of this Convention and other rules of international law, relating to innocent passage through the territorial sea, in respect of all or any of the following:

a) the safety navigation and the regulation of maritime traffic;

\footnotetext{
${ }^{9}$ Maria Maya Lestari, 2017, Study Of The Right Of Foreign Ship Against State Sovereignty (Case Study Indonesia), Indonesian Journal of International Law, Vol. 14 No. 4, P. 499.

${ }^{10}$ Ibid.

${ }^{11}$ United Nations Convention on the Law of the Sea, taken from, https://www.un.org/depts/los/convention agreements/texts/unclos/unclos e.pdf, 23 July 2019.

${ }^{12}$ UNCLOS art. 25 see also in Maria Maya Lestari, Study Of The Right Of Foreign Ship Against State Sovereignty (Case Study Indonesia), Indonesian Journal of International Law, Vol. 14, No. 4, 2017, P. 504.
} 
b) the protection of navigational aids and facilities and other facilities or installations;

c) the protection of cables and pipelines;

d) the conservation of the living resources oft he sea;

e) the prevention of infringement of the fisheries laws and regulations of the coastal State;

f) the preservation of the environment of the coastal State and the prevention, reduction and control of pollution thereof;

g) marine scientific research and hydro graphic surveys;

h) the prevention of infringement of the customs, fiscal, immigration or sanitary laws and regulations of the coastal State. ${ }^{13}$

For navigation safety, coastal States may require foreign ships exercising the right of innocent passage through their territorial sea to use sea lanes and traffic separation scheme as set outin article 22 paragraph 1, provided that such sea lanes and traffic separation scheme must be clearly drawn on the map and must be announced properly as set out in paragraph 4.

\section{Analysis of the Innocent Passage Provisions and State Sovereignty}

The principle of state sovereignty is an important principle in the UN Charter, as stated in Article 2 paragraph (1):"The organization is based on the principle of the sovereign equality of all its members."The principles set out in this UN Charter are reaffirmed in General Assembly Resolution No. 2625 of 1970 (General Assembly Declaration on Principles of International Law concerning Friendly Relations and Cooperation among States in accordance with the Charter of the United Nations) stating that every country enjoys equal sovereignty and has the same rights and obligations as members of the international community irrespective of their economic, social and political systems.

The state is a vessel for the people of a nation is an institution comprises regions, government and people. To support the existence of these elements, a state needs to ensure that all aspects of its life can run well and smoothly, hence the need for sovereignty.

To understand the concept of sovereignty of the sea, the concept of sovereignty it self must first be understood. The first pioneer to discuss the idea of sovereignty as the highest concept of power within the world of science is Jean Bodin. He introduced the term summa protestas, which is synonymous with soveranaite. This term promotes the idea of absolute and authoritarian sovereignty that disregard humans as the actual holder of sovereignty. Bodin's view was then categorized by experts as the concept of State sovereignty suggesting that the state has absolute sovereignty. Furthermore, it was then used by Hugo Grotius in his book entitled De Iure Belle At Pacis. Thomas Hobbes then developed the ideas of the philosophers before him and coined the term sovereignty.

Jimly Asshiddqie describes sovereignty as a dynasty or political regime, such as Daulat Bani Umaiyah, where "daulat" means dynasty, while "bani" means family structure and "umaiyah" is a name taken from the founder's family name, Mu'awiyah. ${ }^{14}$

The concept of supreme power has its own types which are based on the zeitgeist of a nation and the growth of its society during a certain period of time. In addition to that, Jack H. Nagel argues that there are other equally important things in the concept of power, namely the scope of power and domain of power. The scope of sovereignty or

\footnotetext{
${ }^{13}$ Ibid.Article 21.

${ }^{14}$ Jimly Asshiddiqie, Konstitusi dan Konstitusionalisme Indonesia, Penerbit Sekjen dan Kepaniteraan Mahkamah Konstitusi RI, Jakarta, 2006, P.116.
} 
power concerns activities comprising sovereignty function, while the domain of power or sovereignty concerns the subject or sovereignty holder. ${ }^{15}$

Franz Magnis Suseno suggests that sovereignty is the main characteristic of a state, which means that no parties, both inside and outside of a state,can dictate what a state can decide or do. Sovereignty is the absolute, highest, universal,independent and allencompassing right of power. ${ }^{16}$

The relationship between sovereignty and innocent passage is stated in Article 17 of 1982 UNCLOS where it is stated that sovereignty is the basis of the right of innocent passage itself. This article states that ships of all States, both coastal and land-locked, enjoy the right of the innocent passage through the territorial sea. The law of aviation does not recognize the concept of innocent flight. This is based on Article 1of the Chicago Convention of 1944 stating that the contracting States recognize that every State has full and exclusive sovereignty over the air space above its territory. Both scheduled and unscheduled foreign aircrafts still require permission to enter the airspace of another country. As a coastal State, Indonesia has sovereign rights over its territorial sea, the airspace above it, the seabed and the ground beneath it as well as the natural resources contained in it as regulated in the international law. Just like the provisions of an archipelagic State, this convention also obligates the provision of the right of innocent passage to foreign ships and aircrafts so as to let them pass through the territorial sea. ${ }^{17}$

However, the implementation of the right of innocent passage does not always conform with the prohibition norms stated in Article 19 paragraph (2) of 1982 UNCLOS. This is closely related to the security of natural resources and the protection of the sovereignty of a coastal State like Indonesia from potential threats posed by the right of innocent passage through the territorial sea. The use of navigation routes obtained under the right of innocent passage is often associated with the decreasing potential of underwater resources.

One of the important points emphasized in the 1982 UNCLOS is that a coastal State may,for the purpose navigation safety, require foreign ships to exercise the right of innocent passage in navigating through territorial seas by using sea lanes and traffic separation scheme as regulated by Article 22 of the1982 United Nation Convention on the Law of the Sea. The same provision applies to any ships exercising the right of transit passage under Article 41 of the 1982 United Nation Convention on the Law of the Sea governing sea lanes and separation scheme for transit passage, which are applied on states that border with straits.

The right of innocent passage itself applies to all types of ships : merchant ships and governmental ships operated for commercial purposes, warships and other governmental ships operated for non-commercial purposes. ${ }^{18}$

Even though other States may have the right of innocent passage, a coastal State may still be able to suspend or even ban or restrict ships from passing through its territorial sea regime because the sea lies within the sovereignty zone of the said coastal State. A

${ }^{15}$ Franz Magnis Suseno, Etika Politik (Prinsip Moral Dasar Kenegaraan Modern, PT Gramedia Pustaka Utama, Jakarta, 2001, P. 175.

${ }^{16}$ Ibid. P. 175-176.

${ }^{17}$ Kresno Buntoro, Nusantara \& ALKI (Alur Laut Kepulauan Indonesia), PT Raja Grafindo Persada, Depok, 2017, P. 22.

${ }^{18}$ Etty R. Agoes, Konvensi Hukum Laut 1982 dan Masalah Pengaturan Hak Lintas Kapal Asing,Abardin, Bandung, 1991, P. 122. 
suspension can be performed provided that the coastal State is conducting a combat training or has clearly defined reasons, such as for the protection or safety of the State. ${ }^{19}$

Principles of sovereignty at the sea, which is different from the concept of sovereignty in land, must be responded by Indonesian government to prevent the occurrence of violation of the sovereignty at the sea. This is because the sovereignty zone at the territorial sea and archipelagic waters can be passed by ships or aircrafts from other States under the right of innocent passage, and only in inland water zone States have full sovereignty. ${ }^{20}$

\section{The Legal Enforcement of Innocent Passage Against Foreign Ships in Indonesian Territorial Sea}

Just like the provisions of an archipelagic State, this convention also obligates the provision of the right of innocent passage to foreign ships and air crafts so as to let them pass through the territorial sea. However, the implementation of the right of innocent passage does not always conform with the prohibition norms stated in Article 19 paragraph (2) of 1982 UNCLOS. This is closely related to the security of natural resources and the protection of the sovereignty of a coastal State like Indonesia from potential threats posed by the right of the innocent passage through the territorial sea. The use of navigation routes obtained under the right of innocent passage right is often associated with the decreasing potential of the underwater resources. Therefore, security measures are needed to ensure that its implementation is free from activities that negatively impact the sustainability of existing natural resource potentials such as illegal fishing, pollution-generating activities, nuclear radiation from nuclear-powered ships or those carrying nuclear, surveys and so on. To prevent adverse impacts, Article 25 of 1982 UNCLOS grants full authority to coastal States to take preventive measures.

The law enforcement in Indonesia's territorial sea, especially in relation to the right of innocent passage, can be carried out by law enforcers with the following authorities: 1. Authority of the Indonesian Navy (Tentara Nasional Indonesia Angkatan Laut/TNI $\mathrm{AL})$

In performing its duties, the Indonesian Navy (TNI AL) plays 3 (three) important roles, namely the role in the military sector, the role of performing police actions and the role in the field of diplomacy. These three universal roles belong to the Navy. ${ }^{21}$

In their implementation, the three roles are juridically regulated in Law No. 34 of 2004 concerning the Indonesian National Army. The duties that must be carried out by TNI AL have been outlined in Article 9, namely:

a) Carrying out the duties of TNI in the defence sector

b) Upholding the law and maintaining security in the waters under the national jurisdiction in accordance with the provisions of national law and ratified international law

c) Carrying out the duties of Navy diplomacy in order to support foreign policy set by the

${ }^{19}$ Article 25 of 1982 UNCLOS.Rights of protection of the coastal State 1 . The coastal State may take the necessary steps in its territorial sea to prevent passage which is not innocent. 2. In the case of ships proceeding to internal waters or a call at a port facility outside internal waters, the coastal State also has the right to take the necessary steps to prevent any breach of the conditions to which admission of those ships to internal waters or such a call is subject. 3. The coastal State may, without discrimination in form or in fact among foreign ships, suspend temporarily in specified areas of its territorial sea the innocent passage of foreign ships if such suspension is essential for the protection of its security, including weapons exercises. Such suspension shall take effect only after having been duly published.

${ }^{20}$ Maria Maya Lestari, 2017, P. 510.

${ }^{21}$ Dadang Suhendang, Penegakan Hukum Hak Innocent Passage Bagi Kapal-Kapal Asing di Perairan Indonesia. Master of Law Study Program, Faculty of Law, Universitas Brawijaya, Malang, 2015, P.12, accessed http://hukum. studentjournal.ub.ac.id/index.php/hukum/article/view/1285, 6 July 2019. 
government

d) Carrying out the duties of TNI in the development and improvement of naval power

e) Carrying out empowerment of sea defence areas.

2. Authority of the Indonesian National Police (POLRI)/Directorate of Water Police POLRI's status as a law enforcer is based on Law No. 2 of 2002 concerning the Indonesian National Police. Article 13 of Law No. 2 of 2002 stipulates that the main duties of Indonesian National Police are:22

a. Maintaining public security and order,

b. Enforcing the law; and

c. Providing protection, stability and service to the community.

In addition to being carried out by the Criminal Investigation function, law enforcement authority is also carried out by the Water Police in accordance with its main duty, namely fostering and carrying out the functions of the Water Police in order to serve, protect, provide stability and maintain public order and law enforcement in Indonesian waters. $^{23}$

In carrying out its main duties as referred to in Article 13 of Law No. 2 of 2002, the Indonesian National Police shall perform the duties as stated in Article 14 of Law No. 2 of 2002 , namely: ${ }^{24}$

a) implementing arrangements, safeguards, escorts and patrols for the purpose of supporting community and government activities as needed;

b) organizing all activities in ensuring secure, orderly and smooth traffic on the road;

c) providing guidance for the community to drive community participation, community legal awareness and improve community's compliance to the laws and regulations; and so on.

3. Authority of the Ministry of Marine Affairs and Fisheries (KKP)

Article 66 of the Law no. 45 of 2009 concerning Fisheries states that fisheries supervision is carried out by Fisheries Inspector. The Fisheries Inspector has the duty to oversee and ensure that the provisions of fisheries laws and regulations are well implemented. In carrying out its duties, the fisheries inspector is authorized to:

a. Entering and inspecting locations of fisheries business activities;

b. Checking the completeness and validity of fisheries business documents;

c. Monitoring fisheries business activities;

d. Inspecting facilities and infrastructure used for fisheries activities;

e. Verifying the completeness and validity of the Fishing Permit(SIPI) and the Fishing Vessel Permit (SIKPI);

f. Documenting inspection results;

g. Taking samples of fish and/or materials needed for laboratory testing;

$h$. Checking the equipment and activeness of fishing vessel monitoring system;

$i$. Halting, inspecting, securing, detaining and arresting vessels and/or people suspected or reasonably suspected of committing a fishery crime within the territory of the fisheries management of the Republic of Indonesia until the vessels and/or people are handed over at the port, and so on.

4. Authority of the Directorate General of Customs and Excise

\footnotetext{
${ }^{22}$ Pingkan Jeand'arc Angie Doodoh, Tinjauan Yuridis Mengenai Penegakan Hukum Atas Hak Innocent Passage Untuk KapalAsing di Laut Indonesia, Lex Et Societatis, Vol.6, No. 9, November 2018, P. 73.

${ }^{23} \mathrm{http} / /$ www.ditpolairpoldasulteng.com/penegakanhukum-di-perairan-oleh-polair/, accessed on 17 May 2019.

${ }^{24}$ Pingkan Jeand' Angie Doodoh, Loc. cit.
} 
Law No. 17 of 2006 concerning Customs is made as an effort to better guarantee legal certainty, justice, transparency and accountability of public services; to support the efforts of improving and developing the national economy in relation to the global trade; to promote expeditious flow of goods; to increase the effectiveness of the supervision of goods and certain goods entering or exiting Indonesian customs areas;and to optimize the prevention and prosecution of smuggling.

5. Authority of Indonesian Maritime Security Board(IMSB/BAKAMLA)

The Indonesian Maritime Security Board (IMSB) is regulated by Law No. 32 of 2014 concerning Marine Affairs. Article 59 paragraph (3) of Law No. 32 of 2014 states that Indonesian Maritime Security Board is established within the context of the law enforcement in Indonesian territorial waters and jurisdiction, especially in the implementation of security and safety patrols in Indonesian territorial waters and jurisdiction. Indonesian Maritime Security Board is a non-ministerial government institution under and directly responsible to the President through the Coordinating Minister for Political, Legal and Security Affairs (KemenkoPolhukam). The duty of IMSB is to conduct security and safety patrols in Indonesian territorial waters and jurisdiction. $^{25}$

In carrying out its duties, IMSB performs the following functions:

a. Formulating national policies on the security and safety of Indonesian territorial waters and jurisdiction;

b. organizinganearlywarningsystemforthesecurity andsafetyofIndonesianterritorial waters and jurisdiction;

c. performing safeguards against, supervision on, prevention of and prosecution of the violations of law in Indonesian territorial waters and jurisdiction;

d. synergizingand monitoring theimplementation of water patrols by relevantagencies;

e. providing technical and operational support to relevant agencies;

f. providing search and rescue assistance in Indonesian territorial waters and jurisdiction; and

g. performing other duties within the national defense system, and so on.

The enforcement of the law on the right of innocent passage for foreign ships and aircrafts passing through the territorial sea is not an easy task to do. This is due to the disharmony between institutions or government agencies. Duplication of authority among governmental agencies in handling violations related to the right of innocent passage performed by foreign ships and aircrafts is often constrained by duplication of legal norms, inadequate patrol vessel and aircraft fleet forces and political aspects.

The hardships that must be dealt with by the law enforcers in protecting Indonesian territorial sea from possible violations regarding the right of innocent passage are not adequately counter balanced by the capability of the fleet owned by related agencies such as the Indonesian National Police, IMSB and the Navy. The current fleet of ships and aircrafts is far from capable of covering the vast area that must be secured. Furthermore, to successfully deal with the violations regarding the implementation of the right of innocent passage in the territorial sea by foreign ships and aircrafts, cooperation between countries is needed. Diplomatic relations is essential in avoiding prolonged conflict.

According to some theories, the conceptual core and meaning of law enforcement is the relationship between the values described and their activities. The two shall be

\footnotetext{
${ }^{25}$ Article 61 of Law No. 32 of 2014 concerning Marine.
} 
paired with solid rules to generate behaviors that will serve as a series of final stages of value translation aimed at creating, maintaining and sustaining a peaceful life. ${ }^{26}$

Furthermore, according to Soerjono Soekamto, in his book entitled "Faktor-Faktor yangMempengaruhiPenegakanHukum", statesthat themainproblemoflawenforcement actually lies in the factors that might influence it, namely: ${ }^{27}$

1. The legal factor, namely the existing laws.

2. Law enforcement factor, namely those making an implementing the laws.

3. Infrastructure or facilities factors, namely those supporting the law enforcement.

4. Community factor, namely the environment in which the law is applied or implemented.

5. Cultural factor, since law is a product of the labor, idea and emotion built upon people's willin their life.

\section{CONCLUSION}

Ships of all States, both coastal and land-locked, may enjoy the right of the innocent passage through the territorial sea, as long as it is not prejudicial to the peace, good order or security of the coastal state. So, may categories endangers a sovereignty of state if the activities of innocent passage consider endangering the sovereignty of a nation or perform any violations towards the right of innocent passage. The law enforcement in Indonesia's territorial sea, especially in relation to the right of innocent passage, can be carried out by law enforcers with the following authorities: Institutions authorized to perform law enforcement in the sea have a patrol task force, namely TNIAL; POLRI/ Directorate of Water Police (POLAIR); Ministry of Marine Affairs and Fisheries (KKP); Ministry of Finance (Directorate General of Customs and Excise); and IMSB. Each institution has duties and authorities that have been regulated in relevant laws and regulations.

\section{REFERENCES}

\section{Books}

Agoes Etty R., (1991), Konvensi Hukum Laut 1982 dan Masalah Pengaturan Hak Lintas Kapal Asing, Abardin, Bandung.

Asshiddiqie Jimly, (2017), Konstitusi dan Konstitusionalisme Indonesia,Penerbit Sekjen dan Kepaniteraan Mahmakah Konstitusi RI, Jakarta.

Buntoro Kresno, (2017), Nusantara \& ALKI (Alur Laut Kepulauan Indonesia). PT Raja Grafindo Persada, Depok.

Soekanto Soeryono, (1983), Faktor-faktor yang Mempengaruhi Penegakan Hukum, Grafindo Persada, Jakarta.

Richard Swift., N., (1969), International Law, Current and Clasic, New York University.

Suseno Franz Magnis, (2001), Etika Politik (Prinsip Moral Dasar Kenegaraan Modern), PT Gramedia Pustaka Utama, Jakarta.

\section{Journal}

Aguw Youla Olva, (2013), Pengaturan Pemanfaatan Sumber Daya Alam Laut Dan 49 .

${ }^{26}$ Soeryono Soekanto, Faktor-faktor yang Mempengaruhi Penegakan Hukum,Grafindo Persada, Jakarta, 1983, P. ${ }^{27}$ Ibid. 
Pesisir Berbasis Penegakan Hukum Dan Keadilan, Lex Et Societatis,Vol. I, No. 5. September.

Doodoh Pingkan Jeand'arc Angie, (2018), Tinjauan Yuridis Mengenai Penegakan Hukum Atas Hak Innocent passage Untuk Kapal Asing Di Laut Indonesia, Lex Et Societatis, Vol. VI, No. 9. November

Lestari Maria Maya, (2017), Study Of The Right Of Foreign Ship Against State Sovereignty (Case Study Indonesia), Indonesian Journal of International Law, Vol. 14 No. 4.

Massie Cornelis Djelfie, (2015), Law Enforcement Practice of Mlegal Fishing in North Sulawesi Waters, Journal of Law, Policy and Globalizations, ISSN 2224-3240, Vol 40.

\section{Legistions}

Law No. 32 of 2014 concerning Marine.

Law No. 45 of 2009 concerning Fisheries

1982 Sea Law Convention / UNCLOS.

\section{Website}

Http://www.ditpolairpoldasulteng.com/penegakanhukum-di-perairan-oleh-polair/, accessed on May 17, 2019.

United Nations Convention on the Law of the Sea taken from, https://www.un.org/ depts/los/convention_agreements/texts/unclos/unclos_e.pdf, 23 July 2019.

Suhendang Dadang, (2015), Penegakan Hukum Hak Lintas Damai Bagi Kapal-Kapal Asing di Perairan Indonesia, Master of Law Study Program, Faculty of Law, Universitas Brawijaya, Malang, accessed http://hukum.studentjournal.ub.ac. id/index.php/hukum/article/view/1285, 6 July 2019. 